\title{
EXTRACTION OF QUERCETIN FROM POLYGONUM HYDROPIPER L. BY SUBCRITICAL WATER
}

\author{
Lekar, A.V., S.N. Borisenko, E.V. Vetrova, S.N. Sushkova and N.I. Borisenko \\ Institute of Physical and Organic Chemistry, Southern Federal University, Rostov-on-Don, Russia
}

Received 2013-11-01, Revised 2013-11-11; Accepted 2013-11-23

\begin{abstract}
The new method of quercetin extraction from Polygonum hydropiper L. by subcritical water was developed. High performance liquid chromatography was used for identification and quantification of flavonoids in the extract. The new method is environmentally friendly and more effective (7.6-times) than traditional flavonoids extraction methods using expensive and toxic organic solvents.
\end{abstract}

Keywords: Subcritical Water, Flavonoid, Quercetin, Extraction, High Performance Liquid Chromatography

\section{INTRODUCTION}

Bioflavonoids have wide therapeutic action and can be the basis for variety of food additives (Evans and Miller, 1996; Tong-un et al., 2010a) Flavonoids have antioxidant and capillary protective properties and belongs to the group of vitamin $\mathrm{P}$ (Nair et al., 2009).

Environment friendly ways of biologically active substances extraction from plants is important problem while drugs production (Catchpole et al., 2012). Extraction by subcritical water can be one of them.

The subcritical water is the water in a liquid state at temperature varying from 100 to $374{ }^{\circ} \mathrm{C}$ and pressure higher than that of saturated steams to avoid its transition into the gaseous state (Rahmawati and Hayashi, 2012). Subcritical water extraction is one of the most recent techniques developed for extracting organic compounds. Advantage of subcritical water is a considerably variability of such important physical characteristics as a constant of dielectric permeability, a superficial tension, a viscosity. At increased temperatures $\left(100^{\circ} \mathrm{C}-374^{\circ} \mathrm{C}\right)$ and pressure to $218 \mathrm{~atm}$. physical characteristics of subcritical water decrease and water behaves like polar organic solvent.
Leaves and stems of Polygonum hydropiper L. were studied into this study. Polygonum hydropiper L. is an important medicinal plant belonging to the family of Polygonaceae. Flavones and flavonoid glycosides, such as quercetin galactosides, a sesquiterpene acid, viscosumic acid, oxymethylanthraquinones and polygonic acid were identified in all parts of the plant (Furukawa et al., 2002). The plant also has some insecticidal (Kundu et al., 2007), bitter, stimulant, tonic, diuretic, carminative, anthelmintic, haemostatic and lithotripter properties (Sharma, 2003; Choiprasert et al., 2011; Tong-un et al., 2010b).

Plant by its own or mixed with other herbs are used in the treatment of diarrhoea, dyspepsia, itching skin, excessive menstrual bleeding, hemorrhoids (Chevallier, 1996) and other diseases.

Quercetin, one of the flavonoids in fruits and vegetables, has a powerful antioxidant activity both in vitro and in vivo. Claims that quercetin has many biological activities (Umathe et al., 2009; Tong-un et al., 2010a; Choiprasert et al., 2010; Wattanathorn et al., 2007).

The aim of this study is the development of the ecofriendly and effective method for quercetin (Fig. 1) extraction from Polygonum hydropiper L. by subcritical water.

Corresponding Author: Lekar, A.V., Institute of Physical and Organic Chemistry, Southern Federal University, Rostov-on-Don, Russia 
<smiles>O=c1c(O)c(-c2ccc(O)c(O)c2)oc2cc(O)cc(O)c12</smiles>

Fig. 1. Structural formula of quercetin

\section{MATERIALS AND METHODS}

The object of the study was leaves and stems of Polygonum hydropiper L. purchased at retail pharmacies "World of herbs", Russia, (State Pharmacopoeia of the XII edition of the Russian Federation).

Original self-made hardware was used for subcritical water extraction (equipment diagram is shown in Fig. 2).

The dynamic extraction mode (on-flow scheme) was based on liquid state water flow through a raw sample at increased temperature and pressure. Flow extraction was performed in accordance to the previously described protocol. Briefly, a $0.05 \mathrm{~g}$ sample of grinded herb (particles $0.5 \mathrm{~mm}<\mathrm{d}<1.0 \mathrm{~mm}$ ) was put into an extraction cartridge made of stainless steel of $150 \mathrm{~mm}$ length and $4.5 \mathrm{~mm}$ inner diameter. Preliminarily, the extraction cartridge was supplemented with ground glass with the particle size $0.5-1.0 \mathrm{~mm}(0.5 \mathrm{~mL})$ in order to prevent blocking of the filter inside the communications system. Thereafter, the cartridge was connected to the communications system, placed at a thermostat and heated up to the required temperature at a constant distilled water flow velocity $(0.6 \mathrm{~mL} / \mathrm{min})$ and pressure (120 atm) that was provided by an HPLC-type pump (Eldex Labs). When the incubation time (30 min) was over, the water flow stopped.

The resulting aqueous extract was treated with chloroform to remove a ballast substances: Sequentially extracted with ethyl ether three times with $5 \mathrm{~mL}$ ethyl acetate and 3 times with $5 \mathrm{~mL}$. Extracts were dried over anhydrous sodium sulfate for $12 \mathrm{~h}$ evaporated to dryness on a rotary evaporator at $40^{\circ} \mathrm{C}$ and dissolved in $1 \mathrm{~mL}$ of methanol. The obtained extracts were filtered and analyzed by chromatographic analysis.

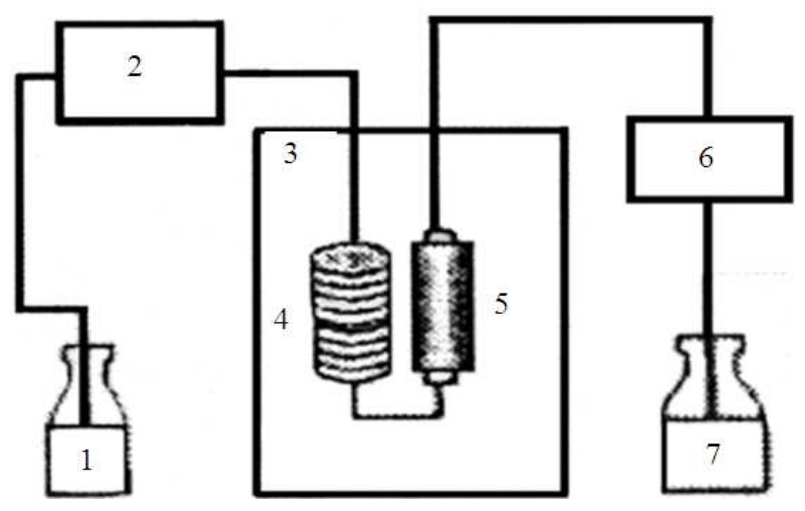

Fig. 2. Scheme of the device which was used for flavonoids extraction from plant samples in subcritical water: 1water tank; 2-pump (Eldex Labs, inc. Menlo Park, CA); 3-thermostat; 4-spiral of thermostat; 5-cartridge; 6pressure restrictor; 7-extract collector

Traditional extraction of quercetin was performed with organic solvents ( $80 \%$ methanol) (Yanga et al., 2012) in several stages. The methanol extraction is carried out as follows: $0.3 \mathrm{~g}$ of air-dried ground plant material was extracted five times with $5 \mathrm{~mL}$ of $80 \%$ methanol. Water-alcohol extracts were combined and evaporated to $1 / 3$ of the initial volume. To remove chlorophyll and tar the extract was washed with chloroform (Xu et al., 2010). The obtained extracts were filtered and analyzed.

For isolation of total flavonoids from methanolic extracts, crude residue was treated sequentially: (1) with diethyl ether 3 times in $5 \mathrm{~mL}$ for the extraction aglycones of flavonoids; (2) then with ethyl acetate three times with $5 \mathrm{~mL}$. In the latter case extracted the monoglycoside of flavonoids and the diglycoside of flavonoids.

Extracts were dried over anhydrous sodium sulfate for $12 \mathrm{~h}$ evaporated and dissolved in $1 \mathrm{~mL}$ methanol for analysis by HPLC chromatography. A typical chromatogram of the extract is shown at Fig. 2. The results are presented in Table 1.

The study of the quercetin's concentration in extract was carried out in the reverse-phase HPLC variant using an "Thermo Separation Products" (Model 2000, Thermo Separation Products, Waltham, MA, USA) HPLC equipment. To analyze samples the following chromatography parameters were selected: Column Spherisorb ODS-2 C18 2.1×150 mm, $3.5 \mu \mathrm{m}$; (speed eluent- $0.4 \mathrm{~mL} / \mathrm{min}$, column temperature $-35^{\circ} \mathrm{C}$, 
UV-detector, $\lambda=353 \mathrm{~nm}$, mobile phase composition: $0.01 \mathrm{M}$ sulfuric acid, acetonitrile, methanol, acetic acid in a ratio of $73: 18: 4: 5$; chromatographic assay time-20 min, sample injection amount-20,00 $\mu \mathrm{L}$ ).

Quantitative estimation of quercetin concentration in extract was performed by the method of absolute calibration with standard quercetin's solutions of differ concentration. Commercial solution of quercetin in acetonitrile (98.2\% purity) (Diaem, Russia) was used as standard. A calibration standard was inserted after every six samples to correct for drift in retention time within a run. The linear range of concentrations was defined (3-15 $\mu \mathrm{g} \mathrm{mL}$ ). An equation of the calibration curve of the peak area of concentration: $\mathrm{S}$ $=100366 \mathrm{C}-39725$, where C-concentration of quercetin, $\mu \mathrm{g} \mathrm{mL}$. The relative error of determination does not exceed $4,5 \%$.

\section{RESULTS}

In order to evaluate the advantages of the proposed method, the subcritical water extraction results $\left(250^{\circ} \mathrm{C}\right)$ were compared with results obtained by traditional methanol extraction (Table 1).

The chromatogram of extract from Polygonum hydropiper L. leaves obtained by subcritical water is shown at Fig. 3.
The data in Table 1 shows that the amount of quercetin extracted by subcritical water is in 7.6 higher than that obtained by the traditional method of extraction. The total amount of flavonoids in the extract obtained in subcritical water is lower than in conventional methanol extraction. Moreover, this method does not require use of expensive and toxic organic solvents.

\section{DISCUSSION}

In order to study the causes of such behavior, the extraction by subcritical water was carried out in several temperatures $\left(100,150\right.$ and $250^{\circ} \mathrm{C}$, extraction time 30 min). The data in Table 2 demonstrated that the amount of extracted quercetin in subcritical water comparable to the amount of quercetin obtained by the traditional method of extraction $\left(44.0 \mathrm{mg} \mathrm{g}^{-1}\right)$. That is, there is a full recovery of the free quercetin from the plant matrix.

This makes it possible to surmise that water heating from 100 to $250^{\circ} \mathrm{C}$ facilitate the release of bound quercetin. In addition, this may be due to the hydrolysis of flavonoid glycosides present in plants (such as rutin and quercetin galactosides). This is supported decreasing the amount of flavonoids in extracts by subcritical water made compared to conventional extraction results (Table 2).

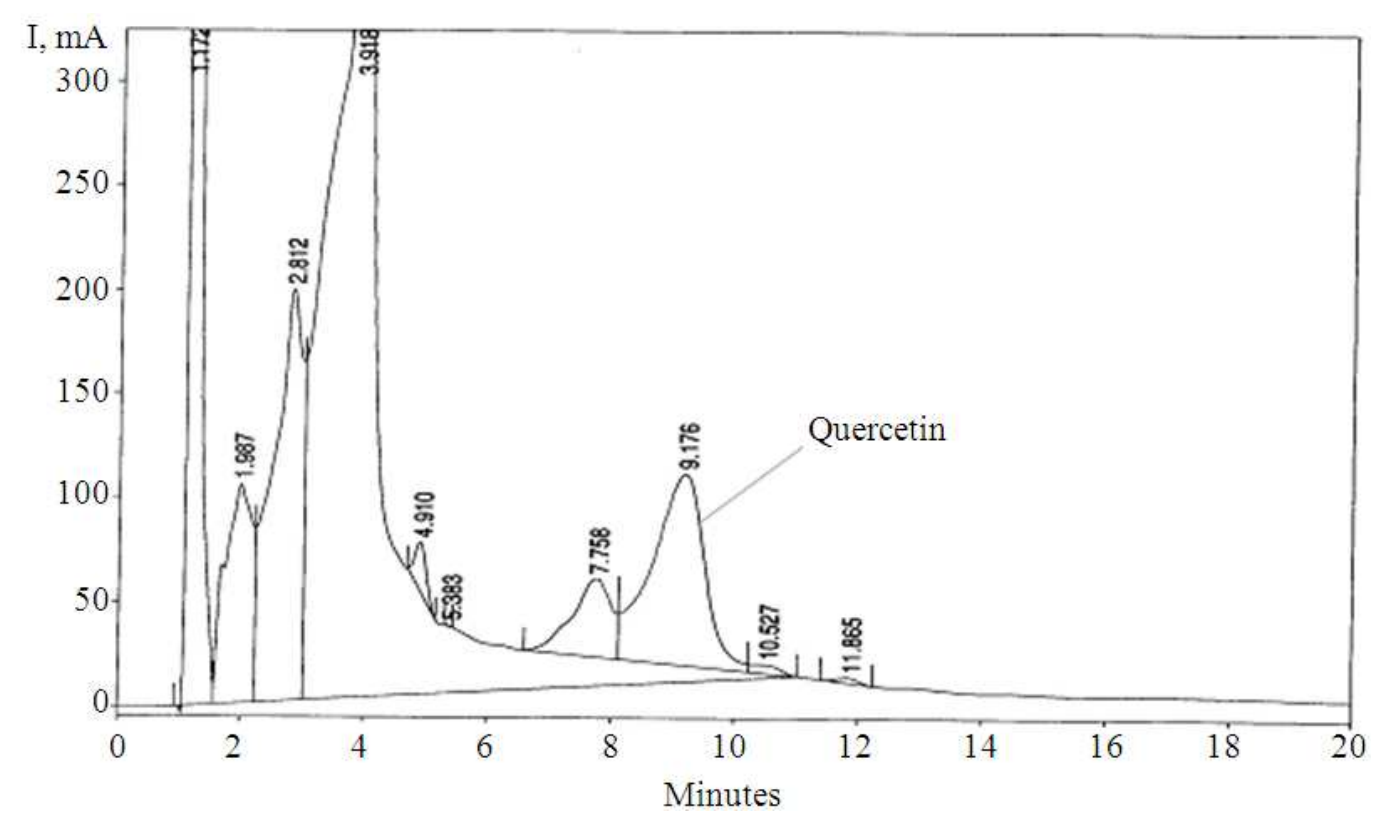

Fig. 3. Typical chromatogram extracts of Polygonum hydropiper L 
Table 1. Amount of flavonoids and quercetin in extracts of Polygonum hydropiper $\mathrm{L}$

\begin{tabular}{|c|c|c|c|}
\hline Solvent & $\begin{array}{l}\text { Total amount } \\
\text { of extracted } \\
\text { flavonoids }\end{array}$ & $\begin{array}{l}\text { Quercetin } \\
\text { concentration } \\
(\mu \mathrm{g} / \mathrm{g})\end{array}$ & Ratio $^{c}$ \\
\hline Methanol & 5,8 & 43,1 & 1,0 \\
\hline $\begin{array}{l}\text { Subcritical water } \\
\left(250^{\circ} \mathrm{C}\right)\end{array}$ & 4,8 & 328,0 & 7,6 \\
\hline \multicolumn{4}{|c|}{$\begin{array}{l}\text { a; Total amount of extracted flavonoids identified by HPLC } \\
\left.\text { (peak areas, } \mathrm{mB}^{*} 108\right) \text {; b; Ratio of extracted quercetin between } \\
\text { subcritical water and traditional method }\end{array}$} \\
\hline \multirow{2}{*}{\multicolumn{4}{|c|}{$\frac{\text { Table 2. Quercetin extraction by subcritical water at different }}{\text { Temperatures }}$}} \\
\hline & & & \\
\hline $\begin{array}{l}\text { Number } \\
\text { of sample }\end{array}$ & $\begin{array}{l}\text { Temperature } \\
\left({ }^{\circ} \mathrm{C}\right)\end{array}$ & \multicolumn{2}{|c|}{$\begin{array}{l}\text { Quercetin } \\
\text { concentration }(\mu \mathrm{g} / \mathrm{g})\end{array}$} \\
\hline 1 & 100 & \multicolumn{2}{|c|}{44,0} \\
\hline 2 & 150 & \multicolumn{2}{|l|}{61,3} \\
\hline 3 & 250 & \multicolumn{2}{|l|}{328,0} \\
\hline
\end{tabular}

Similar results we observed at studying extracts of the onion husk. At increasing temperature of subcritical water, quantitative and qualitative composition of the extracts was varied. That leaded to the increasing the amount of aglycones in the extracts, because of acidic hydrolysis of flavonoid glycosides can occur during extraction process in subcritical water (Lekar et al., 2013).

\section{CONCLUSION}

An ecologically friendly and effective method of extraction of the quercetin from Polygonum hydropiper $\mathrm{L}$. in the medium of subcritical water has been proposed.

The method is environmentally friendly and more effective (7.6-times) than traditional extraction methods using expensive and toxic organic solvents.

However, this process is up to four times faster and does not require using expensive and toxic organic solvents.

This, in the future, may allow to develop a technology of selective extraction to obtain extracts with a desired ratio of glycosides and aglycones.

\section{ACKNOWLEDGEMENT}

This study was supported by grant of the Southern Federal University (№ 213.01-24/2013-48) and grants of Russian Foundation for Basic Research № 13-0301318, 13-03-12271.

\section{REFERENCES}

Catchpole, O., S. Tallon, P. Dyer, F. Montanes and T. Moreno, 2012. Integrated supercritical fluid extraction and bioprocessing. Am. J. Biochem. Biotechnol., 8: 263-287. DOI: 10.3844/ajbbsp.2012.263.287

Chevallier, A., 1996. The Encyclopedia of Medicinal Plants. 1st Edn., Dorling Kindersley, ADULT, DK., London Press, ISBN-10: 0789410672, pp: 185.

Choiprasert, W., C. Loetchutinat, N. Dechsupa and S. Mankhetkorn, 2011. Relation between macroscopic binding constant and the anticancer efficacy of the bovine serum albumin-quercetin complex against drugsensitive and drug-resistant cells. Am. J. Biochem. Biotechnol., 7: 10-20. DOI: 10.3844/ajbbsp.2011.10.20

Choiprasert, W., N. Dechsupa, S. Kothan, M. Garrigos and S. Mankhetkorn, 2010. Quercetin, quercetrin except rutin potentially increased pirarubicin cytotoxicity by non-competitively inhibiting the p-glycoprotein-and MRP1 function in living K562/adr and GLC4/adr Cells. Am. J. Pharmacol. Toxicol., 5: 24-33. DOI: 10.3844/ajptsp.2010.24.33

Evans, C.A. and N.J. Miller, 1996. Antioxidant activities of flavonoids as bioactive components of food. Biochem. Soc. Trans., 24: 790-795. DOI: 10.1042/bst0240790

Furukawa, T., A. Eshima, M. Kouya, S. Takio and H. Takano et al., 2002. Coordinate expression of genes involved in catechin biosynthesis in Polygonum hydropiper cells. Plant Cell Rep., 21: 385-389. DOI: 10.1007/s00299-002-0535-Z

Kundu, B.R., R. Ara, M.M. Begum and Z.I. Sarkar, 2007. Effect of bishkatali, Polygonum hydropiper L. plant extracts against the red flour beetle, Tribolium castaneum Herbst. Univ. J. Zool. Rajshahi Univ., 26: 93-97.

Lekar, A.V., O.V. Filonova, S.N. Borisenko, E.V. Maksimenko and E.V. Vetrova et al., 2013. Extraction of Bioflavonoid Mixture from Onion Husk by Subcritical Water. Russian J. Phys. Chem. B, 7: 1-8.

Nair, M.P.N., Z.M. Saiyed, N.H. Gandhi and C.N. Ramchand, 2009. The flavonoid, quercetin, inhibits HIV-1 infection in normal peripheral blood mononuclear cells. Am. J. Infect. Dis., 5: 135-141. DOI: 10.3844/ajidsp.2009.135.141

Rahmawati, S.I. and N. Hayashi, 2012. The effects of batch reactor extraction on antioxidant activity from Scurulla atropurpurea. Am. J. Applied Sci., 9: 337342. DOI: 10.3844 /ajassp.2012.337.342 
Sharma, R., 2003. Medicinal Plants of India: An Encyclopaedia. 1st Edn., Daya Publishing House, Delhi, ISBN-10: 8170353041, pp: 302.

Tong-un, T., P. Wannanon, J. Wattanathorn and W. Phachonpai, 2010a. Cognitive-enhancing and antioxidant activities of quercetin liposomes in animal model of Alzheimer's disease. OnLine J. Biol. Sci., 10: 84-91. DOI: 10.3844/ojbsci.2010.84.91

Tong-un, T., S. Muchimapura, W. Phachonpai and J. Wattanathorn, 2010b. Effects of quercetin encapsulated liposomes via nasal administration: A novel cognitive enhancer. Am. J. Applied Sci., 7:906-913. DOI: 10.3844/ajassp.2010.906.913

Umathe, S.N., P.V. Dixit, J.M. Vaghasiya and N.S. Jain, 2009. Influence of quercetin on diabetes-induced alteration in CYP3A activity and bioavailability of pioglitazone in rats. Am. J. Infect. Dis., 5: 118-125. DOI: 10.3844/ajidsp.2009.118.125
Wattanathorn, J., W. Phachonpai, A. Priprem and S. Suthiparinyanont, 2007. Intranasal administration of quercetin liposome decreases anxiety-like behavior and increases spatial memory. Am. J. Agric. Biol. Sci., 2: 31-35. DOI: 10.3844/ajabssp.2007.31.35

$\mathrm{Xu}, \mathrm{R}$., Y. Ye and W. Zhao, 2010. Introduction to Natural Products Chemistry. 1st Edn., CRC Press, ISBN-10: 1439860769, pp: 381.

Yanga, Y., T. Yua, H.J. Jangb, S.E. Byeona, S.Y. Songc et al., 2012. In vitro and in vivo antiinflammatory activities of Polygonum hydropiper methanol extract. J. Ethnopharmacol., 139: 616625. DOI: 10.1016/j.jep.2011.12.003 